\title{
MINAT WIRAUSAHA MAHASISWA PROGRAM STUDI AGRIBISNIS PADA MASA PANDEMI COVID-19
}

\author{
Nindya Ayu Pratiwi, Ihsannudin* \\ Program Studi Agribisnis, Fakultas Pertanian, Universitas Trunojoyo Madura \\ Jl. Raya Telang PO BOX 2 Kamal, Bangkalan 69162 \\ *Corresponding author: ihsannudin@trunojoyo.ac.id
}

\begin{abstract}
Amount 5.73\% of the national unemployed are college graduates, and it got worse with $15.6 \%$ of layoffs due to Covid-19. This condition can be solved by entrepreneurship initiation for college graduates, especially agribusiness students. This research aims to determine the strategic development of entrepreneur interest for agribusiness students due to the Covid-19 pandemic, through (1) analyzing the entrepreneurship interest of Agribusiness students, (2) analyzing the driving and inhibiting factors of entrepreneurship interest for Agribusiness students. The approach of this research is quantitative with descriptive analysis. The location was in the Agribusiness department Faculty of Agriculture, University of Trunojoyo Madura. The results show entrepreneurship interest of Agribusiness students is high. Personal characteristics, business knowledge/skills, and social environment were identified as inhibiting factors for entrepreneurship interest, and the driving factor was the family environment. Academic activity strategies need to be carried out by developing entrepreneurship courses, entrepreneurship curriculum development and adapting materials according to the needs of new entrepreneurs. Meanwhile, non-academic strategies are carried out by increasing participation in PKM and entrepreneurship competitions through incentives, requiring participation in entrepreneurship courses in a pleasant atmosphere, writing training/seminars, and other entrepreneurial activities.
\end{abstract}

Keywords: agribusiness, Covid-19, entrepreneurship, student

\begin{abstract}
Abstrak: Tercatat 5,73\% pengangguran nasional merupakan lulusan perguruan tinggi dan semakin memburuk dengan adanya 15,6\% PHK akibat pandemi Covid-19. Kondisi ini perlu diatasi melalui inisiasi wirausaha bagi lulusan perguruan tinggi khususnya mahasiswa agribisnis. Penelitian bertujuan menemukan strategi peningkatan minat wirausaha mahasiswa program studi agribisnis di masa pandemi Covid-19 dengan (1) menganalisis minat mahasiswa program studi Agribisnis berwirausaha, (2) menganalisis faktor pendorong dan penghambat mahasiswa program studi Agribisnis untuk berwirausaha. Pendekatan penelitian ini dilakukan secara kuantitatif menggunakan analisis deskriptif. Lokasi penelitian dilakukan di program studi Agribisnis, Jurusan Ilmu dan Teknologi Pertanian Fakultas Pertanian Universitas Trunojoyo Madura. Hasil penelitian menunjukkan minat wirausaha mahasiswa program studi Agribisnis tinggi. Sifat personal, pengetahuan/keterampilan bisnis dan lingkungan sosial teridentifikasi menjadi faktor penghambat minat wirausaha, dan faktor pendorongnya adalah lingkungan keluarga. Strategi kegiatan akademik perlu dilakukan dengan pengembangan matakuliah kewirausahaan, pengembangan kurikulum wirausaha serta penyesuaian materi sesuai kebutuhan wirausaha baru. Sedangkan strategi non-akademik dilakukan melalui peningkatan keikutsertaam PKM dan lomba kewirausahaan melalui pemberian insentif, mewajibkan keikutsertaan dalam matakuliah kewirausahaan dengan suasana menyenangkan; pelatihan/seminar kepenulisan dan kegiatan kewirausahaan lainnya.
\end{abstract}

Kata kunci: agribisnis, Covid-19, wirausaha, mahasiswa 


\section{PENDAHULUAN}

Lulusan perguruan tinggi di Indonesia memiliki trend yang semakin bertambah setiap tahunnya. Namun dengan lapangan kerja yang terbatas menjadikan banyak lulusan tidak terserap dunia kerja. Berkaca pada data BPS (2020), lulusan perguruan tinggi berkontribusi sebesar 5,73\% dari jumlah pengangguran nasional. Kondisi ini diperkirakan semakin memburuk dengan adanya pandemi Covid-19. Sebagaimana catatan Ngadi et al., (2020), terdapat 15,6\% pemutusan hubungan kerja (PHK) yang menjadikan pengangguran makin bertambah akibat semakin sedikitnya lapangan kerja.

Memperhatikan kondisi demikian, maka wirausaha dapat dijadikan salah satu alternatif solusi. Wirausaha dapat mengubah kondisi ekonomi di masa pandemi Covid-19 serta dapat meningkatkan kesejahteraan ekonomi melalui penciptaan lapangan kerja (Pamungkas et al., 2020). Tetapi sangat disayangkan minat wirausaha mahasiswa masih rendah. Nurhadifah dan Sukanti (2018) mengatakan bahwa rendahnya minat wirausaha mahasiswa terjadi karena adanya kecenderungan mahasiswa tertarik menjadi pekerja setelah lulus kuliah.

Perlu penelitian minat wirausaha mahasiswa di Indonesia, dengan harapan minat wirausaha dikalangan mahasiswa dapat meningkat. Minat adalah perlu memfokuskan perhatian pada unsur perasaan, kesenangan, kesamaan hati, dan timbulnya hasrat tanpa disengaja yang sifatnya selalu menerima sesuatu dari lingkungannya (Achru, 2019). Terbentuknya minat dipengaruhi oleh faktor internal, faktor eksternal, dan faktor emosional (Makabori dan Tapi, 2019). Berdasarkan teori perilaku terencana atau Theory of Planed Behavior (TPB) minat merupakan variabel yang akan membentuk sebuah perilaku, dimana minat terbentuk dari sikap, norma subjektif, dan perilaku kontrol (Ajzen, 1991). Selanjutnya Ajzen (1991) menjelaskan sikap adalah menilai baik atau buruk atas perilaku yang ditanyakan, norma subjektif mengacu pada tekanan sosial dari orang sekitar untuk melakukan suatu perilaku, serta kontrol keperilakuan mengacu pada kemudahan atau kesulitan yang dirasakan dalam melakukan perilaku. Cano dan Tabares (2017) menyatakan sikap perilaku dan persepsi kontrol menjadi lingkungan internal sedangkan norma subjektif menjadi lingkungan eksternal. Lingkungan internal dan eksternal memiliki peran yang berbeda bagi setiap mahasiswa yang dapat saja menjadi penghambat ataupun menjadi pendorong minat wirausaha. Lingkungan internal dan eksternal yang menjadi penghambat dan pendorong dapat berupa mental psikologis, waktu, tenaga, pikiran, keluarga, lingkungan pergaulan, pendanaan, pengelolaan, dan pendampingan (Poerwanto dan Yuniarto, 2013).

Melihat kondisi ini pemerintah turut mendorong minat wirausaha di kalangan mahasiswa melalui PP 17/2010 tentang pengelolaan dan penyelenggaraan pendidikan. Regulasi tersebut secara eksplisit mengungkapkan, tujuan perguruan tinggi adalah membentuk insan yang kritis, kreatif, inovatif, mandiri, percaya diri, serta berjiwa wirausaha. Konsekuensinya kewirausahaan menjadi kurikulum yang wajib disampaikan pada mahasiswa (Susilaningsih, 2015). Selain itu, pemerintah juga telah meluncurkan program kewirausahaan merdeka belajarkampus merdeka 2020 yang bertujuan untuk membentuk jiwa kewirausahaan mahasiswa dengan empat kegiatan unggulan yang diharapkan mampu membentuk jiwa kewirausahaan yaitu Workshop Kewirausahaan, Kegiatan Bisnis Manajemen Mahasiswa Indonesia (KBMI), Akselerasi Startup Mahasiswa Indonesia (ASMI), dan pendampingan bisnis oleh praktisi/pengusaha dan dosen (Kemendikbud, 2020).

Regulasi tersebut terindikasi menjadi pendorong kecenderungan untuk meningkatkan minat mahasiswa untuk berwirausaha bahkan untuk jurusan mahasiwa bidang pendidikan sekalipun (Zunaidy dan Ayuningtyas, 2020). Taufik et al. (2018) menggunakan analisis regresi peningkatan minat wirausaha dapat dipengaruhi toleransi risiko, kebebasan dalam bekerja, pendidikan kewirausahaan dan lingkungan sangat memengaruhi minat mahasiswa berwirausaha. Lebih lanjut Supeni dan Putra (2015) menambahkan, penggunaan media sosial di era digital seperti sekarang ini turut mempopulerkan kegiatan wirausaha. Sementara untuk minat wirausaha mahasiswa program studi agribisnis yang notabenenya memiliki kajian bidang usaha pertanian masih belum ada kajian utamanya yang memfokuskan pada kondisi pandemi seperti saat ini. 
Dalam kaitan itu, Agribisnis sebagai salah satu program studi di Universitas Trunojoyo Madura juga telah menerapkan kurikulum kewirausahaan dan MBKM (Merdeka Belajar Kampus Merdeka). Prodi Agribisnis memiliki target menghasilkan lulusan yang mempunyai jiwa wirausaha (Agribisnis-UTM, 2020). Kurikulum kewirausahaan dan program kewirausahaan MBKM diyakini akan mendukung pencapaian target prodi Agribisnis. Upaya ini dibuktikan dengan pengembangan kurikulum kewirausahaan, workshop, dan webinar kewirausahaan dalam implementasi MBKM guna mendorong terbentuknya jiwa kewirausahaan mahasiswa program studi Agribisnis (Agribisnis-UTM, 2020).

Meski demikian terindikasi pembelajaran kewirausahaan dan MBKM di program studi Agribisnis belum tentu menjamin mahasiswa menjadi wirausahawan. Hasil tracer study oleh Oktavina dan Sugiarti (2020) menunjukkan dari 43 responden lulusan 2017, tidak ada satupun mahasiswa Program Studi Agribisnis yang langsung berminat menjadi wirausaha (95\% melamar pekerjaan dan 5\% melanjutkan studi). Artinya, minat mahasiswa program studi Agribisnis menjadi wirausaha masih sangat rendah. Ini menjadi urgen untuk dilakukan penelitian terkait kurikulum ataupun iklim akademik lainnya di program studi Agribisnis.

Melalui pengkajian faktor pendorong dan penghambat minat berwirausaha mahasiswa, akan didapatkan desain program kewirausahaan dalam upaya mendorong minat berwirausaha mahasiswa (Poerwanto dan Yuniarto, 2013). Desain kewirausahaan ini akan menjadi strategi menumbuhkan minat wirausaha mahasiswa. Strategi yang dapat diterapkan antara lain melalui kegiatan akademik ataupun non akademik berbasis (Akbar, 2018). Melalui strategi tersebut maka akan terbentuk program kewirausahaan yang sesuai kebutuhan mahasiswa sehingga dinyakini mampu mengembangkan minat wirausaha dikalangan mahasiswa. Gramescu (2016) menambahkan inovasi yang tumbuh di suatu kalangan komunitas tertentu seperti komunitas mahasiswa akan mengefektifkan tumbuhnya kewirausahaan.

Untuk itu penelitian ini berupaya menemukan strategi peningkatan minat wirausaha mahasiswa agribisnis Universitas Trunojoyo Madura utamanya di masa pandemi Covid-19 dengan menganalisis minat mahasiswa agribisnis untuk berwirausaha dan mengkaji faktor pendorong dan penghambat mahasiswa agribisnis untuk berwirausaha.

\section{METODE PENELITIAN}

Penelitian ini merupakan penelitian deskriptif dengan pendekatan kuantitatif guna melihat dan menggambarkan objek dengan angka serta menarik kesimpulan dari objek yang diteliti (Putra 2015). Penelitian dilaksanakan di Program Studi Agribisnis Jurusan Ilmu dan Teknologi Pertanian Fakultas Pertanian Universitas Trunojoyo Madura pada periode April 2021 sampai selesai. Populasi penelitian adalah mahasiswa program studi Agribisnis Jurusan Ilmu dan Teknologi Pertanian Fakultas Pertanian Universitas Trunojoyo Madura angkatan 2017 dan 2018 sejumlah 229 orang. Alasan dipilihnya mahasiswa angkatan 2017 dan 2018 karena telah menempuh banyak matakuliah yang berkaitan dengan kewirausahaan. Teknik pengambilan sampel menggunakan disproportional random sampling. Teknik ini digunakan dengan alasan populasinya berstrata dengan pengambilan sampel yang tidak dibagi berdasarkan strata (Sugiyono 2015). Sampel yang digunakan dalam penelitian ini sebanyak 60 orang, dimana 30 orang dari angkatan 2017 dan 30 orang dari angkatan 2018. Berdasarkan Roesco dalam Sari dan Rohman (2015)jumlah ini dinilai telah memenuhi. Gambaran indikator pengukuran dalam penelitian ini dapat dilihat pada Tabel 1.

Data penelitian bersumber dari data primer yang dikumpulkan melalui observasi dan wawancara tertutup menggunakan kuisioner. Instrumen penelitian menggunakan skala likert dengan gradasi dari sangat positif ke sangat negatif. Pengukuran dengan empat skala yaitu, $4=$ Sangat Setuju, $3=$ Setuju, $2=$ Tidak Setuju, 1 = Sangat Tidak Setuju. Sedangkan studi pustaka diperoleh dari berbagai informasi seperti buku, blog Agribisnis, jurnal, BPS, dan sumber lain yang mendukung.

Guna mencapai tujuan yang telah dirumuskan dimana tujuan pertama terkait mengetahui minat wirausaha mahasiswa 
Pratiwi, N. A., Ihsannudin : Minat Wirausaha Mahasiswa Program Studi Agribisnis ...

Tabel 1. Definisi dan indikator variabel

\begin{tabular}{|c|c|c|c|c|}
\hline Variabel & Sub Variabel & Definisi & Indikator & Sumber \\
\hline Minat Wirausaha & & $\begin{array}{l}\text { Keinginan } \\
\text { berwirausaha }\end{array}$ & $\begin{array}{l}\text { Niat yang tinggi menjadi } \\
\text { wirausaha setelah lulus } \\
\text { Niat menjadi wirausaha dibanding } \\
\text { pekerjaan lain }\end{array}$ & $\begin{array}{l}\text { Aditya dan } \\
\text { Fitria, } 2020\end{array}$ \\
\hline \multirow[t]{2}{*}{$\begin{array}{l}\text { Lingkungan } \\
\text { Internal }\end{array}$} & Personal & $\begin{array}{l}\text { Niat serta } \\
\text { pendorong dan } \\
\text { kendala niat } \\
\text { dalam diri } \\
\text { seseorang } \\
\text { untuk menjadi }\end{array}$ & $\begin{array}{l}\text { Tingkat ketertarikan menjadi } \\
\text { wirausaha } \\
\text { Tingkat kemenarikan menjadi } \\
\text { wirausaha } \\
\text { Wirausaha memiliki pengaruh } \\
\text { yang positif }\end{array}$ & $\begin{array}{l}\text { Aditya dan } \\
\text { Fitria, } 2020\end{array}$ \\
\hline & $\begin{array}{l}\text { Pengetahuan/ } \\
\text { Keterampilan } \\
\text { Bisnis }\end{array}$ & wirausaha & $\begin{array}{l}\text { Pengetahuan wirausaha dari } \\
\text { pelajaran kampus } \\
\text { Softskill wirausaha yang dimiliki } \\
\text { diperoleh dari kegiatan diluar } \\
\text { perkuliahan }\end{array}$ & \\
\hline \multirow[t]{2}{*}{$\begin{array}{l}\text { Lingkungan } \\
\text { Eksternal }\end{array}$} & Keluarga & $\begin{array}{l}\text { Lingkungan } \\
\text { sosial yang } \\
\text { memengaruhi } \\
\text { wirausaha }\end{array}$ & $\begin{array}{l}\text { Pengaruh orang tua untuk menjadi } \\
\text { wirausaha } \\
\text { Pengaruh keluarga untuk menjadi } \\
\text { wirausaha }\end{array}$ & $\begin{array}{l}\text { Aditya dan } \\
\text { Fitria, } 2020\end{array}$ \\
\hline & Sosial & & $\begin{array}{l}\text { Pengaruh teman dalam /luar } \\
\text { kampus } \\
\text { Pengaruh dosen untuk menjadi } \\
\text { wirausaha }\end{array}$ & \\
\hline \multirow{2}{*}{$\begin{array}{l}\text { Strategi } \\
\text { Menumbuhkan } \\
\text { Minat Wirausaha }\end{array}$} & $\begin{array}{l}\text { Kegiatan } \\
\text { Akademik }\end{array}$ & $\begin{array}{l}\text { Upaya } \\
\text { menarik }\end{array}$ & $\begin{array}{l}\text { Kegiatan perkuliahan dalam } \\
\text { menumbuhkan minat wirausaha }\end{array}$ & $\begin{array}{l}\text { Akbar, 2018; } \\
\text { Supeni dan }\end{array}$ \\
\hline & $\begin{array}{l}\text { Kegiatan Non } \\
\text { Akademik }\end{array}$ & $\begin{array}{l}\text { berwirausaha } \\
\text { dan berani } \\
\text { menanggung } \\
\text { risiko untuk } \\
\text { sukses }\end{array}$ & $\begin{array}{l}\text { Kegiatan praktek perkuliahan } \\
\text { dalam menumbuhkan minat } \\
\text { wirausaha } \\
\text { Kegiatan seminar kewirausahaan } \\
\text { dalam menumbuhkan minat } \\
\text { wirausaha } \\
\text { Kegiatan PKM dan lomba } \\
\text { kewirausahaan lain }\end{array}$ & Putra, 2015 \\
\hline
\end{tabular}

Agribisnis, tujuan kedua untuk mengidentifikasi faktor pendorong dan penghambat mahasiswa Agribisnis berwirausaha, dan tujuan ketiga mengenai merumuskan strategi penumbuhan minat berwirausaha dianalisis menggunakan analisis deskriptif.

$P=\frac{f}{N} x 100 \%$

Keterangan:

$\mathrm{P} \quad=$ Persentase

$\mathrm{F} \quad=$ Frekuensi

$\mathrm{N}$ = Jumlah responden

Selanjutnya agar mudah dipahami terkait tingkat minat wirausaha, faktor yang menjadi pendorong dan penghambat minat wirausaha, serta strategi yang dapat menumbuhkan minat wirausaha, maka data diolah lebih lanjut menggunakan analisis patokan mean ideal (Mi) dan standar deviasi ideal (SDi) dengan skala dari (Fadjriah 2019).

\section{HASIL DAN PEMBAHASAN}

\section{Minat Wirausaha Mahasiswa Agribisnis}

Jumlah mahasiswa program studi Agribisnis Universitas Trunojoyo Madura mengalami pertambahan setiap tahunnya. Hal ini membuat mahasiswa semakin sulit untuk mendapatkan pekerjaan karena lapangan kerja yang terbatas. Mengingat hal itu, kewirausahaan memiliki peran penting dalam menciptakan lapangan kerja baru. Identifikasi minat wirausaha mahasiswa bertujuan untuk mengetahui tingkat minat wirausaha mahasiswa Agribisnis. Berdasarkan analisis deskriptif didapatkan nilai 
mean, nilai maks, dan nilai min variabel minat wirausaha berturut-turut sebesar 12,93; 16; dan 8. Selanjutnya nilai maksimum, dan minimum digunakan untuk mencari nilai $M i$ dan $S D i$ dengan perhitungan sebagai berikut:

$M i=1 / 2 \times($ skor tertinggi + skor terendah $)$

$M i=1 / 2 \times(16+8)=12$

$S D i=1 / 6 \times$ (skor tertinggi - skor terendah)

$S D i=1 / 6 \times(16-8)=1,33$

Sebanyak 36 responden atau $60 \%$ menyatakan memiliki minat wirausaha yang tinggi. Nilai mean variabel minat wirausaha sebesar 12,93 berada pada kategori tinggi. Tingginya minat wirausaha mahasiswa program studi Agribisnis dikarenakan mahasiswa memiliki ketertarikan terhadap wirausaha dengan adanya niat yang tinggi untuk menjadi wirausaha setelah lulus serta niat yang tinggi untuk menjadi wirausaha dibandingkan pekerjaan lain. Mahasiswa tertarik terhadap dunia wirausaha dikarenakan responden mahasiswa sebagai generasi milenial yang lahir antara tahun 1998-2000 an dengan karakter suka kebebasan dan memperoleh keterbukaan informasi luas. Dalam Budiati et al. (2018), generasi milenial berminat terhadap wirausaha karena milenial menganggap dengan wirausahadapat memperoleh kebebasan dalam bekerja dan dapat mengembangkan dirinya. Hal ini menghasilkan temuan yang berbeda terkait urgensi yang dijelaskan pada latar belakang. Perbedaan ini muncul karena minat yang dikaji pada bagian ini terkait ketertarikan mahasiswa terhadap wirausaha. Temuan ini perlu dikaji lebih mendalam menggunakan teori perilaku terencana atau Theory of Planned Behavior (TPB) untuk melihat apakah minat wirausaha mahasiswa program studi Agribisnis benarbenar tinggi dan mahasiswa benar-benar memilih wirausaha dibandingkan pekerjaan lainsehingga dapat dilihat kecenderungan mahasiswa dalam memutuskan untuk membuka usaha. Sebagaimana Sidrat et al. (2016) tentang teori perilaku terencana dijelaskan bahwa minat wirausaha seseorang dalam menentukan tindakan yang sebenarnya untuk menjadi wirausaha. Hal yang mengindikasikan lingkungan internal dan lingkungan eksternal mahasiswa berperan sebagai pendorong ataupun penghambat terbentuknya minat wirausaha mahasiswa.

\section{Faktor Penghambat dan Pendorong Minat Wirausaha Mahasiswa}

Minat wirausaha mahasiswa program studi Agribisnis terbentuk dari faktor-faktor yang berperan menjadi penghambat dan pendorong minat wirausaha. Faktor-faktor ini berupa lingkungan internal yang terdiri dari personal dan pengetahuan/keterampilan bisnis serta lingkungan eksternal yang terdiri dari lingkungan keluarga dan lingkungan sosial. Lingkungan ini menjadikan kedekatan mahasiswa terhadap kegiatan kewirausahaan. Pérez et al (2021) menyatakan bahwa kedekatan dengan kegiatan kewirausahaan akan mampu memoderasi minat mahasiswa menjadi wirausaha.

Tabel 2. Patokan kategori

\begin{tabular}{ll}
\hline Rentang Nilai $(i)$ & Kategori \\
\hline$X>(M i+1 S D i)$ & Sangat Tinggi/Sangat Mendukung \\
$M i \leq X \leq(M i+1 S D i)$ & Tinggi/Mendukung \\
$(M i-1 S D i) \leq X<M i$ & Rendah/Kurang Mendukung \\
$X<(M i-1 S D i)$ & Sangat Rendah/Tidak Mendukung \\
\hline
\end{tabular}

Sumber: Fadjriah , 2019

Keterangan:

$M i=1 / 2 \times($ skor tertinggi + skor terendah $)$

$S D i=1 / 6 \times$ (skor tertinggi - skor terendah)

Tabel 3. Kategori minat wirausaha mahasiswa

\begin{tabular}{lccl}
\hline Rentang Nilai $(i)$ & Frekuensi & Persentase (\%) & Kategori \\
\hline$X>13,33$ & 17 & 28,34 & Sangat Tinggi \\
$12 \leq X \leq 13,33$ & 36 & 60,00 & Tinggi \\
$10,67 \leq X<12$ & 2 & 3,33 & Rendah \\
$X<10,67$ & 5 & 8,33 & Sangat Rendah \\
Total & 60 & 100,00 & \\
\hline
\end{tabular}

Sumber: Data Primer Diolah, 2021 


\section{Lingkungan internal}

Variabel lingkungan internal memiliki sub variabel personal, yaitu ketertarikan menjadi wirausaha serta anggapan wirausaha memberi pengaruh positif. Selanjutnya sub variabel pengetahuan/keterampilan bisnis berupa keterampilan dalam mengembangkan ide, pengetahuan perencanaan, pengelolaan pembukuan, membuat produk inovatif dan kreatif, pemasaran, pengalaman, dan mental. Hasil analisis deskriptif pada sub variabel personal dan sub variabel pengetahuan/ keterampilan bisnis menunjukkan nilai mean pada setiap sub variabel berturut-turut 34,44 dan 24,02. Selain itu, dari analisis deskriptif diperoleh nilai maks dan min, dimana nilai maks dan min pada sub variabel personal sebesar 40 dan 29 serta nilai mak dan min sub variabel pengetahuan/keterampilan bisnis sebesar 32 dan 17. Selanjutnya perlu dilakukan analisis $M i$ dan $S D i$ untuk sub variabel personal.

$M i=1 / 2 \times($ skor tertinggi + skor terendah $)$

$M i=1 / 2 \times(40+29)=34,5$

$S D i=1 / 6 \times($ skor tertinggi - skor terendah $)$

$S D i=1 / 6 \times(40-29)=1,83$

Serta analisis $M i$ dan SDi untuk sub variabel pengetahuan/keterampilan bisnis.

$M i=1 / 2 \times($ skor tertinggi + skor terendah $)$

Mi $=1 / 2 \times(32+17)=24,5$

$S D i=1 / 6 \times$ (skor tertinggi - skor terendah)

$S D i=1 / 6 \times(32-17)=2,5$

Sebanyak 10 responden atau 16,67\% menunjukkan karakter personal yang rendah. Sementara 20 responden atau 33,33\% menunjukkan kepemilikan pengetahuan/ keterampilan bisnis rendah. Nilai mean sub variabel personal dan pengetahuan/ keterampilan bisnis berturut-turut menunjukkan nilai 34,44 dan 24,02 yang berada pada rentang dengan kategori rendah. hasil nilai mean yang berada pada kategori rendah ini menunjukkan sub variabel personal dan pengetahuan/ keterampilan bisnis mahasiswa menjadi penghambat minat wirausaha mahasiswa program studi Agribisnis Universitas. Hal Ini dikarenakan karakter personal mahasiswa program studi Agribisnis masih rendah terkait ketertarikan dan melihat kemenarikan wirausaha serta adanya anggapan bahwa wirausaha berpengaruh positif terkait kejujuran dan kedisiplinan. Adapun pengetahuan/ ketrampilan bisnis mahasiswa program studi Agribisnis juga rendah terkait pengetahuan perencanaan, pengelolaan, pemasaran, pembuatan produk, mental, dan pengalaman.

Rendahnya faktor personal mahasiswa dikarenakan sebanyak 33 responden mahasiswa atau 55\% masih memiliki kekhawatiran yang besar terhadap kegagalan dalam wirausaha. Ketakutan akan kegagalan ini terbentuk karena mahasiswa belum memiliki kepercayaan diri, keyakinan kuat, pengetahuan dan pengelolaan, pengalaman, serta mental dalam memulai usaha. Adanya kekurangan ini menyebabkan mahasiswa beranggapan kegiatan wirausaha tidak selalu menyenangkan, menjadi wirausaha tidak menarik dan wirausaha tidak memberikan pengaruh positif.

Kondisi ini selaras dengan Kiswanto (2017), yang mengatakan bahwa mahasiswa lebih paham akan gambaran kegagalan yang mungkin terjadi dalam kegiatan wirausaha dibandingkan gambaran kesuksesan yang mungkin diraih, sehingga hal positif yang ada

Tabel 4. Kategori lingkungan internal

\begin{tabular}{llccl}
\hline Sub Variabel & Rentang Nilai $(i)$ & Frekuensi & Persentase (\%) & Kategori \\
\hline \multirow{2}{*}{ Personal } & $X>36,33$ & 22 & 36,67 & Sangat Tinggi \\
& $34,5 \leq X \leq 36,33$ & 5 & 8,33 & Tinggi \\
Total & $32,67 \leq X<34,5$ & 10 & 16,67 & Rendah \\
& $X<32,67$ & 23 & 38,33 & Sangat Rendah \\
Pengetahuan/ & $X>27$ & 60 & 100,00 & \\
Keterampilan & $24,5 \leq X \leq 27$ & 10 & 16,67 & Sangat Tinggi \\
Bisnis & $22 \leq X<24,5$ & 15 & 25,00 & Tinggi \\
& $X<22$ & 20 & 33,33 & Rendah \\
Total & & 15 & 25,00 & Sangat Rendah \\
\hline
\end{tabular}

Sumber: Data Primer Diolah, 2021 
Pratiwi, N. A., Ihsannudin : Minat Wirausaha Mahasiswa Program Studi Agribisnis ...

Tabel 5. Kategori lingkungan eksternal

\begin{tabular}{llccl}
\hline Sub Variabel & Rentang Nilai $(i)$ & Frekuensi & Persentase (\%) & Kategori \\
\hline & $X>12$ & 19 & 31,67 & Sangat Mendukung \\
& $10 \leq X \leq 12$ & 28 & 46,67 & Mendukung \\
Lingkungan Keluarga & $8 \leq X<10$ & 11 & 18,33 & Kurang Mendukung \\
\multirow{2}{*}{ Total } & $X<8$ & 2 & 3,33 & Tidak Mendukung \\
& & 60 & 100,00 & \\
Lingkungan Sosial & $X>17,33$ & 10 & 16,67 & Sangat Mendukung \\
& $16 \leq X \leq 17,33$ & 19 & 31,67 & Mendukung \\
Total & $X<14,67$ & 14 & 23,33 & Kurang Mendukung \\
\hline
\end{tabular}

Sumber: Data Primer Diolah, 2021

dalam wirausaha tertutupi oleh ketakutan mahasiswa.

Sementara sebanyak 35 responden atau $58,33 \%$ menyatakan rendahnya pengetahuan/ keterampilan bisnis mahasiswa dikarenakan kurangnya praktik dan kualitas pendidikan kewirausahaan, sehingga pengetahuan/ keterampilan yang dibutuhkan dalam dunia usaha belum didapatkan mahasiswa secara optimal. Pendidikan kewirausahaan memang terbukti menjadi penentu kunci minat berwirausaha (Tung et al. 2020). Lebih lanjut kajian Sidrat et al. (2016) menyatakan bekal wirausaha lulusan perguruan tinggi di Afrika Selatan terkait pengetahuan/keterampilan masih tidak sesuai dengan yang dibutuhkan untuk bertahan di dunia bisnis karena pelatihan dan pendidikan yang kurang baik.

\section{Lingkungan eksternal}

Variabel lingkungan eksternal memiliki dua sub variabel yaitu lingkungan keluarga dan lingkungan sosial. Hasil analisis deskriptif mnunjukkan nilai mean sub variabel lingkungan keluarga sebesar 11,55 dan nilai mean sub variabel lingkungan sosial sebesar 15,95. Selain itu, nilai maks dan min sub variabel lingkungan keluarga sebesar 16 dan 4 serta nilai mak dan min sub variabel lingkungan sosial sebesar 20 dan 12 . Selanjutnya analisis $M i$ dan $S D i$ sub variabel lingkungan keluarga sebagai berikut.

$M i=1 / 2 \times($ skor tertinggi + skor terendah $)$

$M i=1 / 2 \times(16+4)=10$

$S D i=1 / 6 \times$ (skor tertinggi - skor terendah)

$S D i=1 / 6 \times(16-4)=2$

Selanjutnya perhitungan nilai $M i$ dan SDi sub variabel lingkungan sosial.
$M i=1 / 2 \times($ skor tertinggi + skor terendah $)$
$M i=1 / 2 \times(20+12)=16$
$S D i=1 / 6 \times($ skor tertinggi - skor terendah $)$
$S D i=1 / 6 \times(20-12)=1,33$

Sebanyak 28 responden atau 46,67\% menyatakan lingkungan keluarga mendukung. Sementara sebanyak 14 responden atau 23,33\% menyatakan lingkungan sosial kurang mendukung. Nilai mean sub variabel lingkungan keluarga sebesar 11,55 berada pada kategori mendukung serta sub variabel lingkungan sosial dengan nilai mean sebesar 15,95 berada pada kategori kurang mendukung. Hal ini berarti sub variabel lingkungan keluarga menjadi pendorong minat wirausaha mahasiswa program studi Agribisnis. Sama halnya dengan penelitian Oktavina dan Sugiarti (2020) lingkungan keluarga mahasiswa program studi Agribisnis memberikan motivasi pada tingkatan sedang bagi mahasiswa untuk berwirausaha. Sementara Setyaningsih (2014), mengatakan lingkungan keluarga sebenarnya mendukung mahasiswa untuk berwirausaha tetapi kurang mendukung dalam permodalan.

Lingkungan keluarga mendukung minat wirausaha mahasiswa karena sebanyak 96,7\% mahasiswa responden berasal dari keluarga etnis Jawa dan Madura, dimana dua etnis tersebut sudah mengenal wirausaha sejak lama dan memiliki nilai budaya yang terikat dengan nilai kewirausahaan. Temuan ini didukung Sutanto dan Nurrachman (2018), Adi et al. (2020) yang menyatakan menyatakan bahwa etnis Jawa dan etnis Madura memiliki sejarah panjang dalam perdagangan serta memiliki karakter yang lekat dengan wirausaha seperti kemandirian, kerja keras, ulet dan pantang menyerah. Selain itu, dukungan lingkungan 
keluarga terhadap minat berwirausaha mahasiswa karena maraknya kegiatan kewirausahaan yang diadakan oleh instansiinstansi ternama sehingga membentuk perubahan pola pikir bahwa menjadi wirausaha juga menjanjikan secara ekonomi dan sosial (Sandiar dan Narsih, 2019).

Sub variabel lingkungan sosial menjadi penghambat minat wirausaha mahasiswa program studi Agribisnis. Hal ini karena mahasiswa program studi Agribisnis kurang memiliki teman untuk memotivasi berwirausaha. Berdasar hasil temuan, sebanyak 31 responden atau 51,66\% menyatakan kurang memiliki teman yang mampu mendukung dan mengajak berwirausaha bersama, kurang memiliki teman yang telah sukses berwirausaha sehingga menyebabkan mahasiswa kurang termotivasi untuk berwirausaha dari teman. Rendahnya teman yang berwirausaha dikarenakan mahasiswa yang bercita-cita menjadi wirausaha masih sangat sedikit. Demikian juga sangat terbatas mahasiswa yang telah menekuni dunia wirausaha ketika pada masa kuliah. Vilathuvahna dan Nugroho (2015) menyatakan, dari 400 mahasiswa UTM yang bercita-cita menjadi wirausaha hanya sebanyak 68 orang. Sementara Oktavina dan Sugiarti (2020) menyatakan dari 60 orang mahasiswa program studi Agribisnis UTM hanya dua orang yang memiliki cita-cita menjadi wirausaha.

Berdasar hasil kajian lingkungan internal dan eksternal didapatkan faktor penghambat ternyata lebih dominan dibandingkan faktor pendorong dalam membentuk minat wirausaha bagi mahasiswa program studi Agribisnis. Artinya, minat wirausaha mahasiswa program studi Agribisnis sebenarnya masih banyak terkendala yang berimplikasi pada rendahnya keputusan mahasiswa untuk menekuni wirausaha. Ini yang menyebabkan mengapa dalam temuan Oktavina dan Sugiarti (2020) meski minat wirausaha mahasiswa program studi Agribisnis tinggi namun ternyata setelah dikaji terkait cita-cita mahasiswannya hanya ada 3\% yang memiliki cita-cita untuk menjadi wirausaha. Mahasiswa memang memiliki ketertarikan terhadap wirausaha, tetapi mahasiswa belum memiliki bekal yang cukup untuk terjun di dunia wirausaha. Sehingga ketertarikan yang tinggi terhadap wirausaha tidak dapat direalisasikan oleh mahasiswa untuk menjadi wirausaha. Kurangnya bekal kemampuan ini yang membuat mahasiswa kurang bercita-cita menjadi wirausaha. Adanya hambatan-hambatan pembentukan minat wirausaha mahasiswa perlu ada tindakan berupa strategi-strategi untuk mengurangi bahkan menghilangkan hambatan-hambatan tersebut agar minat wirausaha dan kesiapan mahasiswa terjun di dunia usaha dapat tumbuh.

\section{Strategi Menumbuhkan Minat Wirausaha Mahasiswa}

Program Studi Agribisnis dalam rangka menumbuhkan minat wirausaha mahasiswa menerapkan beberapa strategi yaitu dengan kegiatan akademik berupa pendidikan kewirausahaan dan non akademik berupa seminar, Program Kreativitas Mahasiswa (PKM) dan lomba kewirausahaan. Strategistrategi tersebut perlu dibahas terkait kontribusinya dalam menumbuhkan minat wirausaha mahasiswa program studi Agribisnis.

\section{Kegiatan Akademik}

Kegiatan akademik untuk menumbuhkan minat wirausaha mahasiswa Program Studi Agribisnis terdiri atas kegiatan belajar-mengajar terkait kewirausahaan di dalam kelas dan kegiatan praktik terkait kewirausahaan. Berdasar hasil analisis deskriptif nilai mean, maks dan min sub variabel kegiatan akademik berturut-turut menunjukkan nilai 32,48; 40; dan 25. Selanjutnya perlu mencari nilai $M i$ dan $S D i$ kegiatan akademik sebagai berikut.

$M i \quad=1 / 2 \times($ skor tertinggi + skor terendah $)$

$M i \quad=1 / 2 \times(40+25)=32,5$

$S D i=1 / 6 \times$ (skor tertinggi - skor terendah)

$S D i=1 / 6 \times(40-25)=2,5$

Sebanyak 28 responden atau 46,67\% menyatakan kegiatan akademik kurang mendukung. Nilai mean sub variabel kegiatan akademik hanya sebesar 32,48 atau berada pada kategori kurang mendukung. Kondisi ini mengindikasikan kegiatan akademik masih kurang mendukung dalam menumbuhkan minat wirausaha mahasiswa program studi Agribisnis. Sebanyak 35 responden atau 58,34\% menyakan praktik kewirausahaan belum memadai dalam memberikan edukasi dan keterampilan terkait kemampuan penciptaan produk inovatif dan kreatif, pemasaran produk, akses sumberdaya finansial dan penanganan risiko. 
Pratiwi, N. A., Ihsannudin : Minat Wirausaha Mahasiswa Program Studi Agribisnis ...

Tabel 6. Kategori kegiatan akademik dalam menumbuhkan minat wirausaha

\begin{tabular}{llccl}
\hline Sub Variabel & Rentang Nilai $(i)$ & Frekuensi & Persentase (\%) & Kategori \\
\hline & $X>35$ & 11 & $18,33 \%$ & Sangat Mendukung \\
Kegiatan Akademik & $32,5 \leq X \leq 35$ & 14 & $23,33 \%$ & Mendukung \\
& $30 \leq X<32,5$ & 28 & $46,67 \%$ & Kurang Mendukung \\
Total & $X<30$ & 7 & $11,67 \%$ & Tidak Mendukung \\
\hline
\end{tabular}

Sumber: Data Primer Diolah, 2021

Tabel 7. Kategori seminar kewirausahaan menumbuhkan minat wirausaha

\begin{tabular}{lccl}
\hline Rentang Nilai $(i)$ & Frekuensi & Persentase (\%) & Kategori \\
\hline$X>12,67$ & 32 & 54,24 & Sangat Mendukung \\
$11 \leq X \leq 12,67$ & 24 & 40,68 & Mendukung \\
$9,33 \leq X<11$ & 2 & 3,39 & Kurang Mendukung \\
$X<9,33$ & 1 & 1,69 & Tidak Mendukung \\
Total & 59 & 100,00 & \\
\hline
\end{tabular}

Sumber: Data Primer Diolah, 2021

Hal ini sejalan dengan temuan Sidrat et al. (2016) yang menyatakan pendidikan dan pelatihan kewirausahaan di Afrika Selatan yang buruk berdampak pada rendahnya keterampilan lulusan untuk terjun sebagai wirausaha baru. Lebih lanjut Sidrat et al. (2016) menyatakan buruknya pendidikan dan pelatihan tersebut dikarenakan adopsi sistem yang tidak sesuai dengan yang dibutuhkan mahasiswa. Dalam memberikan pendidikan dan pelatihan kewirausahaan harus disesuaikan dengan kebutuhan mahasiswa sebagai bekal memulai bisnis baru. Agar kegiatan akademik mampu menumbuhkan minat wirausaha optimal, matakuliah kewirausahaan perlu ada mulai semester awal dan tetap ada hingga semester akhir serta perlu terus dilakukan pengembangan kurikulum (Lestari dan Djamilah, 2020; Marhaban, 2017). Pada kasus prodi Agribisnis dapat menerapkan saran ini dengan memberlakukan matakuliah kewirausahaan dari semester satu sampai semester delapan dan membuat pengembangan kurikulum yang adaptif untuk menjadikan matakuliah kewirausahaan menjadi bekal pengetahuan dan pelatihan mahasiswa untuk terjun kedunia bisnis sebagai wirausaha muda.

\section{Kegiatan Non Akademik}

Kegiatan non akademik berupa seminar kewirausahaan sebagai kegiatan peningkatan minat wirausaha mahasiswa menunjukkan bahwa 59 responden atau 98,33\% pernah mengikuti seminar kewirausahaan. Artinya, mahasiswa memiliki antusiasme tinggi untuk mengikuti seminar kewirausahaan. Tingginya antusiasme mahasiswa ini karena ada dorongan dari program studi seperti tuntutan tugas matakuliah tertentu yang mewajibkan mahasiswa mengikuti seminar.

Hasil analisis deskriptif seminar kewirausahaan memiliki nilai mean, maks dan min berturut-turut menjukkan nilai 13,25; 16 dan 6. Adapun perhitungan nilai $M i$ dan $S D i$ seminar kewirausahan adalah sebagai berikut.

$M i=1 / 2 \times($ skor tertinggi + skor terendah $)$

$M i=1 / 2 \times(16+6)=11$

$S D i=1 / 6 \times($ skor tertinggi - skor terendah $)$

$S D i=1 / 6 \times(16-6)=1,67$

Sebanyak 32 atau 54,24\% menyatakan seminar kewirausahaan sangat mendukung. Nilai mean kegiatan seminar kewirausahaan sebesar 13,25 atau masuk kategori sangat mendukung. Ini mengindikasikan seminar kewirausahaan sangat mendukung penumbuhan minat wirausaha mahasiswakarena memberikan motivasi dan menambah wawasan wirausaha. Ini terjadi karena dalam kegiatan seminar yang menjadi pembicara merupakan orang-orang berpengalaman dan wirausaha sukses sehingga keberadaan orang-orang tersebut dapat memotivasi dan membuka wawasan terhadap wirausaha. Misalnya ketika dihadirkan pemateri pelaku usaha madu yang memulai usaha dari bawah dapat menjadikan inspirasi dan motivasi bagi mahasiswa. Sama halnya dengan temuan Afridayani dan Mu'arif (2021), wirausaha berpengalaman yang didatangkan dalam acara seminar dapat meningkatkan emosi mahasiswa untuk berwirausaha. Oleh karena itu, seminar kewirausahaan perlu terus 
dilaksanakan mengingat besarnya pengaruh dalam menumbuhkan minat wirausaha.

Program Kreativitas Mahasiswa (PKM) juga memiliki peranan penting dalam menumbuhkan minat wirausaha mahasiswa Agribisnis. Sebanyak 46 orang atau $76,67 \%$ pernah mengikuti kegiatan PKM. Meskipun nilainya lebih dari 50\%, nilai ini masih menunjukkan mahasiswa belum cukup memiliki antusiasme mengikuti PKM. Dinyatakan antusias apabila 100\% mahasiswa mengikuti PKM karena memang keiikutsertaan dalam PKM sebenarnya diwajibkan saat mengikuti mata kuliah ini. Kurangnya antusias mahasiswa dalam mengikuti PKM karena mahasiswa tidak ingin waktu untuk mengerjakan tugas berkurang. Na'imatul et al. (2015) mengatakan mahasiswa lebih mementingkan mengerjakan tugas dan lebih senang melakukan aktivitas lain dibandingkan mengikuti PKM yang menyita banyak waktu. Padahal program studi Agribisnis telah berupaya mendorong mahasiswa untuk mengikuti PKM dengan memberikan insentif dan mewajibkan pembuatan PKM bagi mahasiswa yang mengikuti matakuliah tertentu. Na'imatul et al. (2015) mengatakan bahwa seminar dan pelatihan pembuatan PKM, pemberian hadiah, serta membuat penulisan PKM menjadi hal yang menyenangkan dapat memotivasi mahasiswa untuk mengikuti kegiatan PKM.

Berdasarkan analisis deskriptif, PKM memiliki nilai mean, maks, dan min berturutturut 9,39; 12; dan 6 . Adapun perhitungan nilai Mi dan SDi PKM adalah sebagai berikut.

$M i=1 / 2 \times($ skor tertinggi + skor terendah $)$

$M i=1 / 2 \times(12+6)=9$

$S D i=1 / 6 \times$ (skor tertinggi - skor terendah)

$S D i=1 / 6 \times(12-6)=1$

Sebenarnya, 26 responden atau 56,52\% responden yang pernah mengikuti PKM mengatakan bahwa PKM mendukung minat wirausaha. Nilai mean PKM sebesar 9,39yang masuk kategori mendukung. Dengan kata lain, PKM mendukung dalam menumbuhkan minat wirausaha mahasiswa program studi Agribisnis. PKM dapat menumbuhkan minat wirausaha karena melatih mahasiswa dalam melihat dan memanfaatkan peluang, mengembangkan kreativitas dan inovasi, serta melatih kemampuan kerjasama dan disiplin. Demikian pula dalam penyusunan proposal PKM mahasiswa terlatih untuk menyusun perencanaan usaha. Program studi Agribisnis sendiri dari 6 proposal yang didanai DIKTI, 4 proposal diantaranya adalah PKMkewirausahaan (Agribisnis-UTM, 2013). Ini mengimplikasikan, semakin banyak proposal PKM-K yang didanai DIKTI maka semakin banyak peluang tumbuhnya wirausaha baru. Hendri et al. (2015) mengatakan, proposal PKM-K yang didanai DIKTI dapat menjadi ide bisnis yang dapat dikembangkan menjadi usaha baru bagi mahasiswa.

Lomba kewirausahaan juga dapat menjadi strategi menumbuhkan minat wirausaha mahasiswa. Sebanyak 20 responden atau $33,33 \%$ pernah mengikuti lomba kewirausahaan. Jumlah ini masih menunjukkan antusiasme mahasiswa yang rendah untuk mengikuti lomba kewirausahaan. Rendahnya antusiasme mahasiswa dikarenakan masih ada kebingungan dan kurangnya ide yang perlu dilakukan saat mengikuti lomba kewirausahaan. Upaya yang dapat dilakukan untuk mendorong antusiasme mahasiswa dapat dilakukan dengan membentuk programprogram kewirausahaan (Hernawati dan Yuliniar, 2018).

Melalui proram-program ini akan ada diskusi yang mampu memunculkan ide dan kreativitas berwirausaha. Berdasar analisis deskriptif nilai mean, maks, dan min lomba kewirausahaan menunjukkan nilai 6,30; 8; dan 4.

Tabel 8. Kategori PKM menumbuhkan minat wirausaha

\begin{tabular}{lccl}
\hline Rentang Nilai $(i)$ & Frekuensi & Persentase (\%) & Kategori \\
\hline$X>10$ & 12 & 26,09 & Sangat Mendukung \\
$9 \leq X \leq 10$ & 26 & 56,52 & Mendukung \\
$8 \leq X<9$ & 2 & 4,35 & Kurang Mendukung \\
$X<8$ & 6 & 13,04 & Tidak Mendukung \\
Total & 46 & 100,00 & \\
\hline
\end{tabular}

Sumber: Data Primer Diolah, 2021 
Pratiwi, N. A., Ihsannudin : Minat Wirausaha Mahasiswa Program Studi Agribisnis ...

Tabel 9. Kategori lomba kewirausahaan menumbuhkan minat wirausaha

\begin{tabular}{lccl}
\hline Rentang Nilai $(i)$ & Frekuensi & Persentase $(\%)$ & Kategori \\
\hline$X>6,67$ & 7 & 35 & Sangat Mendukung \\
$6 \leq X \leq 6,67$ & 10 & 50 & Mendukung \\
$5,33 \leq X<6$ & 0 & 0 & Kurang Mendukung \\
$X<5,33$ & 3 & 15 & Tidak Mendukung \\
Total & 20 & 100 & \\
\hline
\end{tabular}

Sumber: Data Primer Diolah, 2021

Sementara perhitungan $M i$ dan SDi lomba kewirausahaan sebagai berikut.

$M i=1 / 2 \times($ skor tertinggi + skor terendah $)$

$M i=1 / 2 \times(8+4)=6$

$S D i=1 / 6 \times$ (skor tertinggi - skor terendah)

$S D i=1 / 6 \times(8-4)=0,67$

Sebanyak 10 responden atau $50 \%$ responden yang pernah mengikuti lomba kewirausahaan menyatakan lomba kewirausahaan turut mendukung minat wirausaha. Nilai mean lomba kewirausahaan sebesar 6,30 menunjukkan kategori mendukung. Ini berarti lomba kewirausahaan mendukung dalam menumbuhkan minat wirausaha mahasiswa program studi Agribisnis. Lomba kewirausahaan seperti lomba Bussiness Plan dapat menumbuhkan minat wirausaha karena mampu memberikan pengalaman pembuatan perencanaan dan pengelolaan bisnisserta mengembangkan ide kreatif mahasiwa. Hal ini terjadi karena dalam lomba kewirausahaan, mahasiswa peserta lomba diminta membuat rencana bisnis yang menjadikan mahasiswa memperoleh pengalaman untuk mengelola, merencanakan dan mengembangkan ide kreatif. Fitriani dan Ma'ruf (2019) mengatakan, pembuatan rencana bisnis menjadikan mahasiswa mampu membuat rancangan anggaran, proses produksi, dan pemasaran.

\section{KESIMPULAN}

Hasil penelitian ini mengungkapkan bahwa minat wirausaha mahasiswa program studi Agribisnis tergolong tinggi. Namun demikian, temuan tersebut tidak dapat dijadikan patokan bahwa mahasiswa program studi Agribisnis dalam memutuskan untuk memulai berwirausaha juga tinggi karena perlu ada kajian lebih lanjut menggunakan teori perilaku terencana. Berdasar kajian teori tersebut menunjukkan bahwa lingkungan keluarga mampu mendorong minat wirausaha mahasiswa program studi Agribisnis. Sementara indikator personal, pengetahuan/ keterampilan bisnis, dan lingkungan sosial justru menghambat minat wirausaha mahasiswa program studi Agribisnis. Berdasarkan hal tersebut, terungkap bahwa sebenarnya minat wirausaha mahasiswa program studi Agribisnis memiliki banyak kendala yang berdampak pada rendahnya keputusan untuk memulai wirausaha. Untuk itu diperlukan strategi untuk menumbuhkan minat wirausaha. Strategi dapat berupa kegiatan akademik maupun non akademik. Strategi kegiatan akademik masih belum mampu menumbuhkan minat wirausaha mahasiswa dengan optimal. Perlu ada pemberlakuan matakuliah kewirausahaan dari semester awal hingga semester akhir, pengembangan kurikulum dan materi wirausaha sesuai kebutuhan mahasiswa sebagai wirausaha baru (adaptif). Materi yang diperlukan terkait dengan perencanaan, pengelolaan, pemasaran, pembuatan produk, mental, dan pengalaman. Sementara strategi kegiatan non akademik berupa seminar kewirausahaan, PKM dan lomba kewirausahaan perlu terus dilanjutkan karena mampu menumbuhkan minat wirausaha. Upaya-upaya tersebut akan lebih meningkatkan antusiasme mahasiswa tatkala ada pemberian insentif, menjadikan kegiatan wajib matakuliah dengan terbangun suasana menyenangkan dan terukur peningkatan kegiatannya.

\section{DAFTAR PUSTAKA}

Achru, A. (2019). Pengembangan minat belajar dalam pembelajaran. Jurnal Idaarah, III(2), 205-215.

Adi, K. R., Idris, \& Rosyida, F. (2020). Internalisasi nilai-nilai kewirausahaan etnis madura. Jurnal Teori dan Praksis Pembelajaran IPS, 5(1), 1-9. 
Aditya, M. L. \& Fitria, S. E. (2020). Analisis minat berwirausaha pada siswa peserta ekstrakurikular kewirausahaan di SMKN 1 Bandung dengan menggunakan theory of planned behavior. E-Proceeding of Management, 7(1), 52-61.

Afridayani \& Mu'arif, S. (2021). Efektivitas pembelajaran entrepreneurship dan seminar motivasi untuk meningkatkan minat menjadi entrepreneur. Scientific Journal of Reflection: Economic, Accounting, Management And Business, 4(1), 160-169.

Agribisnis-UTM. (2013). Blog Prodi Agribisnis Universitas Trunojoyo Madura. Retrieved from http://agribisnis.trunojo yo.ac.id/mahasiswa-program-studiagribisnis-kembali-eksis-melalui-pkm/.

Agribisnis-UTM. (2020). Blog Prodi Agribisnis Universitas Trunojoyo. Retrieved from https://agribisnis.trunojoyo.ac.id/tujuandan-sasaran-program-studi-agribisnis/.

Ajzen, I. (1991). The Theory of Planned Behavior. Organizational Behavior and Human Decision Processes, 50, 179211.

Akbar, A. (2018). Pengembangan sumber daya manusia: minat berwirausaha mahasiswa dengan pola pendidikan soft skills. Jurnal Ekonomi Dan Bisnis Islam, 3(1), 71-87.

BPS. (2020). Keadaan Ketenagakerjaan Indonesia Februari 2020. Jakarta: Badan Pusat Statistik.

Budiati, I., Susianto, Y., Adi, W. P., Ayuni, S., Reagan, H. A., Larasaty, P., \& Saputri, V. G. (2018). Profil Generasi Milenial Indonesia. Jakarta: Kementerian pemberdayaan perempuan dan perlindungan anak.

Cano, J. A., \& Tabares, A. (2017). Determinants of university students entrepreneurial intention: Guesss Colombia study. Revista Espacious, 38, 22-33.
Fadjriah, S. (2019). Hubungan motivasi kerja dan pelatihan kerja dengan kinerja karyawan di rumah sakit umum bakti medan. Jurnal Ilmiah Simantek, 3(4), 121-135.

Fitriani, S. \& Ma'ruf, F. (2019). Membentuk jiwa kewirausahaan melalui pendampingan proposal bisnis. Prosiding Seminar Nasional Hasil Pengabdian kepada Masyarakat Universitas Ahmad Dahlan, 453-58.

Gramescu, L. (2016). Scaling social innovation in europe: an overview of social enterprise readiness. Procedia - Social and Behavioral Sciences, 221, 218-225

Hendri, M. I., Rochayati, I., \& Fahmi, M. (2015). Desain pengembangan aktivitas kemahasiswaan dengan pendekatan psychological capital dalam meningkatkan minat dan kemampuan berwirausaha mahasiswa fakultas ekonomi Untan. Jurnal Ekonomi Bisnis Dan Kewirausahaan, 4(2), 211-227.

Hernawati, E. \& Yuliniar. (2018). Pemetaan potensi dan minat mahasiswa UPN 'Veteran' Jakarta untuk berwirausaha. Ekonomi Dan Bisnis, 5(2), 145-59.

Kemendikbud. (2020). Pendampingan Wirausaha Mahasiswa Indonesia (PWMI) Panduan 2020. Jakarta: Kementerian pendidikan dan kebudayaan.

Kiswanto, A. (2017). Karakteristik rasa takut gagal (fear of failure) pada young entrepreneurial berdasarkan minat karier mahasiswa. Jurnal Fokus Konseling, 3(1), 47-56.

Lestari, N. A. A. U. \& Djamilah, S. (2020). Solusi peningkatan minat wirausaha dan pengurangan hambatan minat wirausaha mahasiswa. Jurnal Manajemen dan Bisnis, 1(1), 1-6.

Makabori, Y.Y. \& Tapi, T. (2019). Generasi muda dan pekerjaan di sektor pertanian: faktor persepsi dan minat (Studi kasus 
Pratiwi, N. A., Ihsannudin : Minat Wirausaha Mahasiswa Program Studi Agribisnis ...

mahasiswa Politeknik Pembangunan Pertanian Manokwari). Jurnal Triton, 10(2), 1-20.

Marhaban. (2017). Strategi prodi manajemen keuangan syariah dalam mengembangkan minat mahasiswa berwirausaha. Ihtiyadh, 1(2), 53-75.

Na’imatul, D., Ambarwati, I., \& Rahmawati, F. (2015). Peningkatan kegemaran menulis karya ilmiah melalui program kreativitas mahasiswa (PKM). Prosiding Seminar Nasional PGSD UMS, 76-80.

Ngadi, Meilianna, R., \& Purba, Y. A. (2020). Dampak pandemi Covid-19 terhadap PHK dan pendapatan pekerja di Indonesia. Jurnal Kependudukan Indonesia, 15(2), 43-48.

Nurhadifah, S. N., \& Sukanti. (2018). Pengaruh kepribadian, lingkungan keluarga, dan teman sebaya terhadap minat berwirausaha mahasiswa Program Studi Pendidikan Akuntansi Fakultas Ekonomi Universitas Negeri Yogyakarta. Jurnal Pendidikan Akuntansi Indonesia, XVI(2), 82-98.

Oktavina, C. N., \& Sugiarti, T. (2020). Motivasi dan minat mahasiswa prodi agribisnis utm terhadap pekerjaan wirausaha. Agriscience, 1(1), 308-323.

Pamungkas, A., Hastuti, I., Ibrahim, M., Putra, C. C., \& Rizqullah, M. D. (2020). Pengembangan peluang kegiatan kewirausahaan mahasiswa Universitas Duta Bangsa Surakarta dalam era new normal di tempat usaha shiftcomp. Prosiding Seminar Nasional PGSD UMS, 27-31.

Pérez, P. C., González, T. T., \& NájeraSánchez, J.J. (2021). Boosting entrepreneurial intention of university students: Is a serious business game the key? The International Journal of Management Education, 100506. https: //doi.org/10.1016/j.ijme.2021.100506.
Poerwanto, G. H., \& Yuniarto, A. Y. (2013). Faktor pendukung dan penghambat mahasiswa Program Sarjana Universitas Sanata Dharma dalam berwirausaha. Jurnal Penelitian, 16(2), 119-132.

Putra, E. A. (2015). Anak berkesulitan belajar di sekolah dasar se-Kelurahan Kalumbuk Padang (penelitian deskriptif kuantitatif). Jurnal Ilmiah Pendidikan Khusus, 4(3), 71-76.

Sandiar, L. \& Narsih, D. (2019). Pembuatan proposal bisnis guna menanamkan minat berwirausaha pada siswa MTS Nurul Hikmah Kabupaten Bekasi. Journal of Empowerment Community, 1(2), 59-66.

Sari, P. T. \& Rohman, A. (2015). Persepsi mahasiswa atas pengaruh teknologi informasi terhadap kualitas informasi akuntansi dengan etika pengguna sebagai variabel moderasi. Diponegoro Journal of Accounting, 4(2), 1-11.

Setyaningsih, I. (2014). Analisis faktor penghambat keberhasilan mahasiswa menjadi entrepreneur. Prosiding. Seminar Nasional IENACO, 535-41.

Sidrat, S., Amouri, A., Boujelbene, Y., \& Boudabbous, S. (2016). Entrepreneurship In Tunisia: Obstacles. International Journal of Humanities and Social Science Invention, 5(4), 60-67.

Sugiyono. (2015). Metode Penelitian Pendidikan (Pendekatan Kuantitatif, Kualitatif dan R\&D). Bandung: Alfabeta CV.

Supeni, R. E. \& Putra, F. K. (2015). Minat menjadi wirausaha mahasiswa Universitas Muhammadiyah Jember. Jurnal Manajemen Dan Bisnis, 11(2), 137-159.

Susilaningsih (2015). Pendidikan kewirausahaan di perguruan tinggi: pentingkah untuk semua profesi? Jurnal Economia, 11(1), 1-9. 
Sutanto, O. \& Nurrachman, N. (2018). Makna kewirausahaan pada etnis Jawa, Minang dan Tionghoa: Sebuah studi representasi sosial. Jurnal Psikologi Ulayat, 5(1), 86108.

Taufik, A., Azhad, M.N., \& Hafidzi, A.H. (2018). Faktor yang memengaruhi minat berwirausaha mahasiswa. Jurnal Penelitian Ipteks, 3(1), 86-99

Tung, D. P., Hung, N. T., Phuong, N. T. C., Loan, N. T. T., \& Chong, S. C. (2020). Enterprise development from students: the case of universities in Vietnam and the Philippines. The International
Journal of Management Education, 18(1), 100-333.

Vilathuvahna, A. A. \& Nugroho, T. R. D. A. (2015). Intensi kewirausahaan mahasiswa Universitas Trunojoyo Madura. Agriekonomika, 4(1), 107-119.

Zunaedy, M. \& Ayuningtyas, T. (2020). Faktor-faktor yang memengaruhi minat berwirausaha mahasiswa pendidikan ekonomi STKIP PGRI Lumajang tahun akademik 2020/2021. Jurnal Riset Pendidikan Ekonomi (JRPE), 6(1), 4759 